\title{
Could FaRP-like peptides participate in regulation of hyperosmotic stress responses in plants?
}

\author{
François Bouteau ${ }^{1,2}$ *, Yann Bassaglia, ${ }^{3,4}$, Emanuela Monetti ${ }^{1,2}$, Daniel Tran ${ }^{1}$, Sandra Navet ${ }^{1}$, \\ Stefano Mancuso ${ }^{2,5}$, Hayat El-Maarouf-Bouteau ${ }^{6}$ and Laure Bonnaud-Ponticelli ${ }^{3}$ \\ 1 Sorbonne Paris Cité, Institut des Energies de Demain, Université Paris Diderot, Paris, France \\ 2 LINV-DiSPAA, Department of Agri-Food and Environmental Science, University of Florence, Sesto Fiorentino, Italy \\ ${ }^{3}$ Muséum National d'Histoire Naturelle, DMPA, Sorbonne Universités, UMR BOREA MNHN-CNRS 7208-IRD 207-UPMC-UCBN, Paris, France \\ ${ }^{4}$ Faculté des Sciences and Technologies, Université Paris Est Créteil-Val de Marne (UPEC), Créteil, France \\ ${ }^{5}$ Sorbonne Paris Cité, Paris Interdisciplinary Energy Research Institute (PIERI), Université Paris Diderot, Paris, France \\ 6 UPMC UMR7622-IBPS, Paris, France
}

\section{Edited by:}

Sylvie Dufour, Muséum National d'Histoire Naturelle, France

Reviewed by:

Stacia A. Sower, University of New Hampshire, USA

Christian Mazars, Centre National de la Recherche Scientifique, France

\section{*Correspondence:}

François Bouteau, Sorbonne Paris

Cité, Institut des Energies de Demain,

Université Paris Diderot, Case

Courrier 7040 Lamarck, Paris Cedex

1375205 , France

e-mail: francois.bouteau@

univ-paris-diderot.fr
The ability to respond to hyperosmotic stress is one of the numerous conserved cellular processes that most of the organisms have to face during their life. In metazoans, some peptides belonging to the FMRFamide-like peptide (FLP) family were shown to participate in osmoregulation via regulation of ion channels; this is, a well-known response to hyperosmotic stress in plants. Thus, we explored whether FLPs exist and regulate osmotic stress in plants. First, we demonstrated the response of Arabidopsis thaliana cultured cells to a metazoan FLP (FLRF). We found that $A$. thaliana express genes that display typical FLP repeated sequences, which end in $R F$ and are surrounded by $K$ or $R$, which is typical of cleavage sites and suggests bioactivity; however, the terminal G, allowing an amidation process in metazoan, seems to be replaced by W. Using synthetic peptides, we showed that amidation appears unnecessary to bioactivity in $A$. thaliana, and we provide evidence that these putative FLPs could be involved in physiological processes related to hyperosmotic stress responses in plants, urging further studies on this topic.

Keywords: Arabidopsis thaliana, drought, FaRP-like peptides, osmotic stress, stomata

\section{INTRODUCTION}

Most of the living organisms from bacteria to metazoans, fungi, and plants have to face hyperosmolarity (i.e., an external osmolarity that is higher than the physiological range) during their lifetime, and the establishment of an appropriate response can be a matter of life or death. Whatever the cell types, they are generally able to counteract volume perturbations following a shift in extracellular osmolarity by rapidly modulating the activities of their plasma membrane ion transport systems $(1,2)$. Several major hormones that respond to osmotic stress have been identified in metazoans, vertebrates to arthropods, and plants (3-9), but it is only more recently that the importance of small peptides in different regulatory mechanisms has been pointed out in metazoans and plants $(10,11)$. In numerous metazoans (mollusks, annelids, nematodes, and vertebrates), peptides belonging to the FMRFamide-like peptides (FLPs) family have been shown to participate in osmoregulation $(12,13)$. Moreover, FLPs were shown to target various ion channels, among them the membrane sodium channels, such as the amiloride-sensitive FMRFa-activated sodium channel $(\mathrm{FaNaCh})$ in invertebrates (13), or the structurally related acid-sensing sodium channels (ASICs) in vertebrates (14). These ligand-gated or $\mathrm{pH}$ sensitive- $\mathrm{Na}^{+}$channels are involved in $\mathrm{Na}^{+}$ permeability and associated water transport, which makes them

Abbreviations: FaRPs, FMRFamide related peptides; FLPs, FaRP-like peptides; PM, plasma membrane; $\mathrm{V}_{\mathrm{m}}$, plasma membrane potential. critical determinants of cell volume regulation (14). In sensory neurons of Aplysia, chloride currents are evoked by FMRFa via the cGMP cascade (15). In the same type of neurons, FMRFa also modulates the probability of opening and closing of S-type $\mathrm{K}^{+}$channels, a stretch-activated channel involved in response to osmotic shock (16).

For plant, drought-induced osmotic stress and salinity represent some of the major constraints that adversely affect growth, development, and biomass production. Numerous cellular responses and proteins have been reported to be conserved between plant and animal cells (17-19). Among them are ion channels (20), and their involvement in response to hyperosmotic stress (2, 21-23). Recent works implicate small signaling peptides in developmental processes in plants (11), but to our knowledge, until now, no study has described the presence of FLPs in viridiplantae. Thus, we addressed the hypothesis that FLPs exist in plants and participate in their physiological responses to hyperosmotic stress. Moreover, since many discoveries with direct relevance to animal biology have been elaborated using plants (17), this topic could also be relevant for metazoan biology by bringing new insight in FLPs structures, functions, and evolution.

\section{MATERIALS AND METHODS CELL CULTURE CONDITIONS}

Arabidopsis thaliana L. cell suspensions were freshly prepared from calli of the cell line T87 (24), which was generated from the ecotype Columbia plant. They were maintained in Gamborg 
culture medium complemented with $20 \mathrm{~g} \mathrm{~L}^{-1}$ sucrose, $2 \mathrm{mg} \mathrm{L}^{-1}$ $2,4 \mathrm{D}, 0.1 \mathrm{mg} \mathrm{L}^{-1}$ kinetin at $22 \pm 2^{\circ} \mathrm{C}$ under continuous white light $\left(40 \mu \mathrm{E} \mathrm{m}^{-2} \mathrm{~s}^{-1}\right)$ with continuous shaking (gyratory shaker at $120 \mathrm{rpm})$, as previously described $(24,25)$. Cell suspensions were sub-cultured weekly using a 1:10 dilution. All experiments were performed at $22 \pm 2{ }^{\circ} \mathrm{C}$ using log-phase cells (4 days after sub-culture). Cell density was about $3.10^{4}$ cells $\mathrm{mL}^{-1}$.

\section{ELECTROPHYSIOLOGY}

Cells were impaled in the culture medium with borosilicate capillary glass (Clark GC 150F) micropipettes (resistance: $50 \mathrm{M} \Omega$ when filled with $600 \mathrm{mM} \mathrm{KCl}$ ). Main ion concentrations in the medium after 4 days were $9 \mathrm{mM} \mathrm{K}^{+}, 11 \mathrm{mM} \mathrm{NO}_{3}^{-}$(26). Individual cells were voltage-clamped using an Axoclamp 2B amplifier (Axon Instruments, Foster City, CA, USA) as previously described (24).

\section{HYPEROSMOSIS TEST AND CELL VIABILITY ASSAYS}

Pretreatments of $15 \mathrm{~min}$ with the various plants putative FLPs were done prior to the induction of a hyperosmotic stress by a $400 \mathrm{mM}$ sorbitol exposure (duration: $6 \mathrm{~h}$ ). Hyperosmosis-induced cell death in the cell suspension culture was determined after staining the dead cells with Evans blue $(0.005 \%$, w/v) for $10 \mathrm{~min}$. Cells were counted under a microscope and cells accumulating Evans blue were considered to be dead. At least 500 cells were counted for each independent treatment and the procedure was repeated at least three times for each condition.

\section{MEASUREMENT OF INTRACELLULAR ROS LEVEL}

For measuring reactive oxygen species (ROS) generation, we used the CellROX ${ }^{\circledR}$ Deep Red Reagent (Molecular probes). The cellpermeant dye is non-fluorescent in a reduced state, and exhibits bright fluorescence upon oxidation by ROS. The cells were preincubated for $15 \mathrm{~min}$ with $100 \mu \mathrm{M}$ of peptides and then incubated with $400 \mathrm{mM}$ Sorbitol during $1 \mathrm{~h}$. The cells were incubated with $5 \mu \mathrm{M}$ CellROX Deep Red for 30 min before recording and then were washed with phosphate-buffered saline buffer. The excitation wavelength was set at $640 \mathrm{~nm}$, and the emission was detected at $665 \mathrm{~nm}$ (27). The fluorescence intensity of the cells was measured with a Tecan Infinite 200 Spectrophotometer.

\section{SEEDLINGS CULTURE}

Arabidopsis thaliana L. seedlings were grown in an environmentally controlled chamber ( $8 \mathrm{~h}$ photoperiod, under $100 \mu \mathrm{mol}$ photons $\mathrm{m}^{-2} \mathrm{~s}^{-1}$ at the leaf level, $24 \pm 2^{\circ} \mathrm{C}$ ) and plants were weekly watered.

\section{PREPARATION OF EPIDERMAL STRIPS}

Arabidopsis thaliana leaves from 4 to 6 weeks old plants were harvested $1 \mathrm{~h}$ after the beginning of the light period. Epidermal strips were carefully prepared from abaxial epidermis then placed cuticle side-down on microscope slides covered with medical adhesive (Dow Corning 355, Peters surgical) and immediately floated in $10 \mathrm{mM}$ MES pH 6.1, $50 \mathrm{mM} \mathrm{KCl,} 1 \mathrm{mM} \mathrm{CaCl}_{2}$ (opening buffer) under white light $\left(40 \mu \mathrm{mol}\right.$ photons $\left.\mathrm{m}^{-2} \mathrm{~s}^{-1}\right)$, or in $10 \mathrm{mM}$ MES $\mathrm{pH} 6.1,10 \mathrm{mM} \mathrm{KCl}, 1 \mathrm{mM} \mathrm{CaCl} 2$ (closing buffer) in dark, for $3 \mathrm{~h}$ before future treatments.

\section{STOMATAL APERTURE MEASUREMENTS}

Epidermal strips were analyzed with a Laborlux S (Leica, Germany) microscope $(\times 400)$. For quantifying, microscope fields were digitalized with a Kappa CF11DSP (Nikon, Japan) digital camera. The width of the stomatal aperture was measured using the image analysis software Metreo Kappa Image Base (Kappa, Germany). The pore width from at least 65 stomata from 2 leaves was measured per treatment and pooled together for statistical analysis. Data are expressed as micrometer and are means \pm SE.

\section{CHEMICALS}

Synthetic peptides (purity $>95 \%$ ) were purchased from Proteogenix (Oberhausbergen, France) and diluted in water.

\section{IN SILICO ANALYSIS}

Putative plant FLP precursors were detected using a blastp search against the protein sequence database at the NCBI and TAIR, using FMRF-FMRF, FLRF-FLRF, or ILRF-ILRF as query. Only sequences showing more than three repeats were considered. Further sequences were obtained using these results as query using blastp against the UniProtKB database. All sequences were also blasted using tblastn against $A$. thaliana ESTs database at the NCBI and TAIR. When possible, the corresponding genes were localized using the EnsemblPlant database. Some representative sequences are presented in Table 1.

\section{STATISTICS}

Significant differences between treatments were determined by the Mann and Whitney test, and $P$ values $<0.05$ were considered significant.

\section{RESULTS AND DISCUSSION FLRFa-INDUCED HYPERPOLARIZATION AND ION CURRENT REGULATIONS IN ARABIDOPSIS THALIANA CELLS}

FMRFamide (FMRFa) is a cardioexcitatory peptide that was first isolated from the nervous system of the clam, Macrocallista nimbosa (28), and is active as a tetrapeptide only in mollusks and annelids. Other active tetrapeptides have been identified in lophotrochozoans; these include FLRFa, YLRFa, or YMRFa. In view of the well-known effects of FLPs on ion channel regulation in metazoan cells, we first checked for the putative effect of FLRFa, a typical metazoan FLP, on plasma membrane polarization and ion channel regulations in cultured cells of the model plant $A$. thaliana by using single electrode voltage clamp (24). In control conditions (in culture medium), the cell plasma membrane potential $\left(\mathrm{V}_{\mathrm{m}}\right)$ of cells was $-33 \pm 4 \mathrm{mV}(n=20)-$ similar to those we observed in previous studies $(25,26,29)$. Addition of $100 \mu \mathrm{M}$ FLRFa induced a hyperpolarization of the cells of $-8 \pm 1.5 \mathrm{mV}(n=4$, Figure 1A). These FLRFa-induced hyperpolarizations were correlated with a decrease in inward currents (Figures 1B,E) that we previously described as anion currents (25, $26,30)$, and an increase in time dependent outward rectifying currents (Figures 1B,E), previously described as $\mathrm{K}^{+}$outward currents [KORC, $(24,26,30)]$. It is noteworthy that these ion current regulations are the same as those observed in response to a shift in osmolarity (128-330 mOsm induced by addition of $200 \mathrm{mM}$ sorbitol in the cell culture medium; Figures 1C-E). Inhibition 
Table 1 | Identification of some putative pro-peptides and their genes in Arabidopsis thaliana

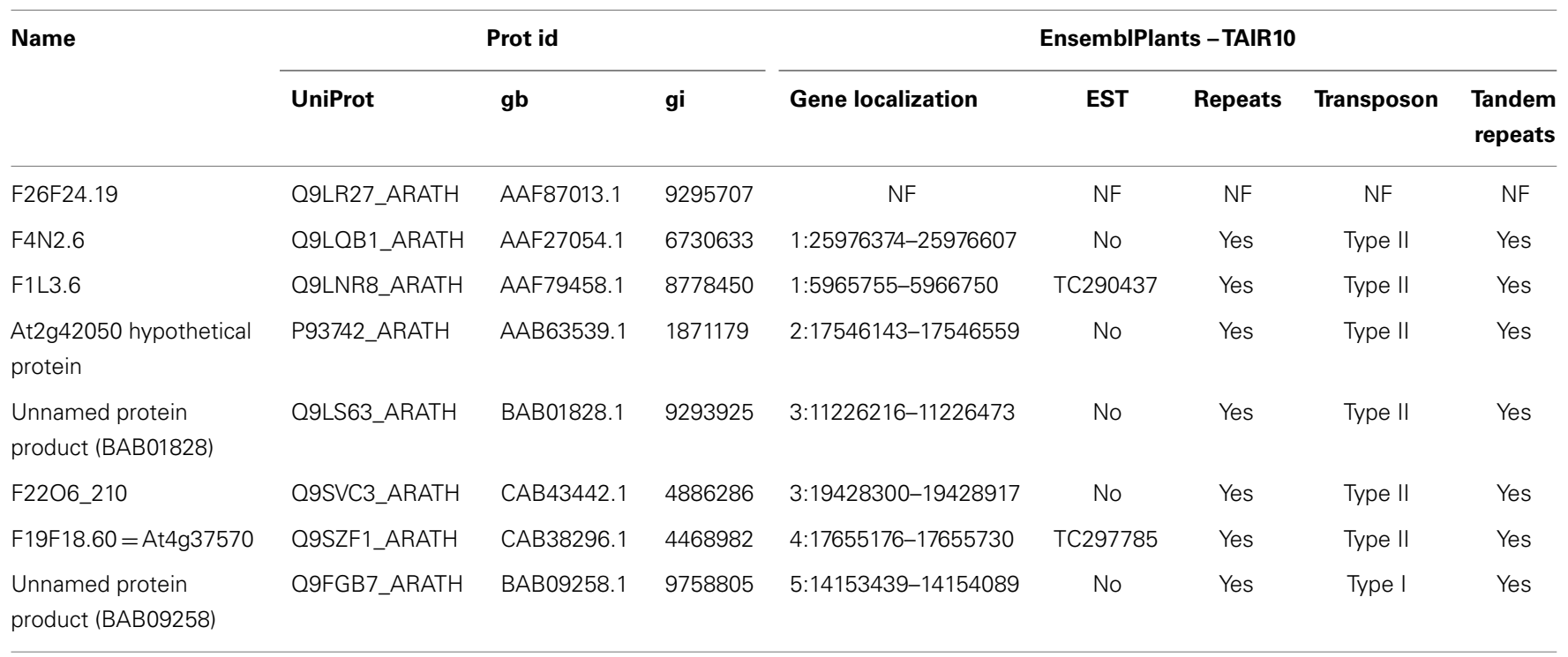

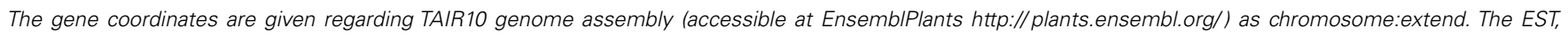
repeats, transposon, and tandem are the automatic annotations given during the automatic annotation procedure. NF, not found.

of outward anion currents is a process by which ion leakage is decreased, and thus, results in rapid adaptation to hyperosmotic condition by ion accumulation (31-33). The activation of KORC favoring $\mathrm{K}^{+}$efflux previously reported in other models $(34,35)$ is opposite to ion accumulation but could be a part of an initial signaling that could result in osmotic regulation (34). In view of these data, we searched for putative plant gene(s) coding for these peptides in gene and protein databases.

\section{PUTATIVE CANDIDATE GENES FOR FLPS SYNTHESIS IN ARABIDOPSIS THALIANA}

A FLP can be defined as a peptide that ends in RFa while a FaRP is a peptide homologous to FMRFa in metazoans $(36,37)$. The number of FLPs identified is increasing with the availability of genome and transcriptome databases and the development of constrained algorithm to search for them $(37,38)$. The length of these peptides ranges from 4 to 52 amino-acids and $37 \%$ of those found do not exceed 10 amino-acids (36). Active peptides are cleaved-out of a pro-peptide; the amino-acids allowing this cleavage are the basic amino-acids K or R, either alone or as a dimer (39) (Figure 2A). In FaRPs, the terminal cleavage site $(\mathrm{R} / \mathrm{K})$ is preceded by a $\mathrm{G}$, allowing the amidation of the peptide: the XXRFamide form is biologically active, whereas a non-amidated peptide is considered to be inactive. Regarding FLP, the structure $[\mathrm{KR}](\mathrm{X})_{\mathrm{n}} \mathrm{RFG}[\mathrm{KR}]$ appears to be the most common organization (Figure 2A). Nevertheless, the amino-acid before the RF ends may vary between peptides and/or organisms. Espinoza et al. (38) have shown that the distribution and the type of amino-acids (the order and the respective position) of each is not random. Although the specificity of each peptide seems to be very high and adapted to each species [see for example (40-42)], the structure and the relationships between structure (composition) and function of the genes, as well as the biochemical characteristic of the couple ligand/receptor, are not clearly established.
By exploring genomic and transcriptomic databases, we found in A. thaliana, several putative genes that may allow the production of pro-peptides including repeated FLPs peptide sequences. Some representative sequences are listed in Table 1 and illustrated in Figure 2. As underlined in Table 1, most of these sequences are not annotated as ESTs in the automatic genome annotations, probably because of the "repeat masker" step. Instead, they are interpreted to be transposable elements. But several similar sequences were found in A. thaliana ESTs database, suggesting that these genes could in fact be expressed (for example: EG509196 and EG509184). It is noteworthy that the ESTs are issued from Arabidopsis stressed with several factors, including salinity, an osmotic stress.

The sequences in Figure $2 \mathrm{~A}$ were initially identified using a poly-ILRF query and all of them showed the characteristic properties of pro-peptides: tandem repeats and cleavage sites. Each sequence of the alignment in Figure 2B presents 3-12 repeats ending with RF. In these sequences, the IL[RK]F feature is the most abundant. The ILRF sequence is one classical ending identified among the 23 groups of longer metazoan FaRPs (38). Conventional cleavage sites ( $\mathrm{R}$ or $\mathrm{K}$ ) are present, suggesting a RENMIL[R,K]FWR peptide sequence. As observed in other genes/species, all the repeats are not followed and/or preceded by a putative cleavage site; these unbreakable repeats are often interpreted as non-functional.

Other repeated peptides with FLPs-like structures have been evidenced. Figure 2C illustrates a group of sequences rich in KI[MIST]GLRFWR and also presenting other putative peptides. Each of these five sequences are found on different chromosomes, indicating that they correspond to different genes.

The peptide ILRF (and YLRF) is found in several combinations of metazoan peptides, suggesting that this peptide could be functional, at least in metazoans (37). This observation, combined with biological effect of tetrapeptide in Arabidopsis cells shown above, 
A

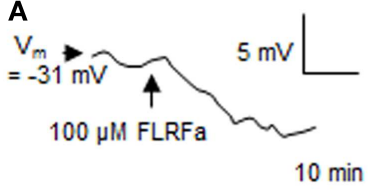

B
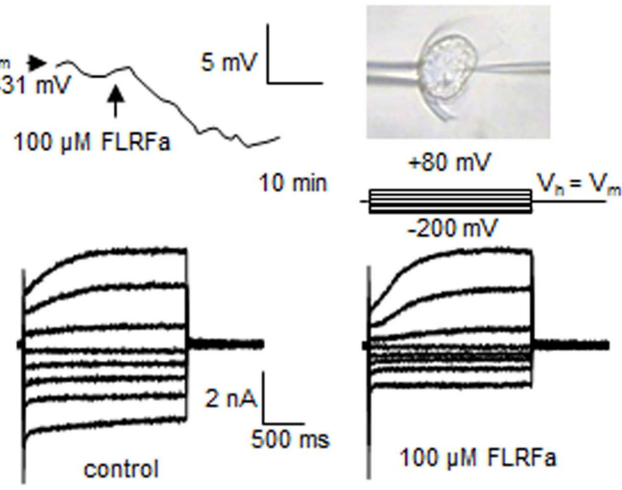

C

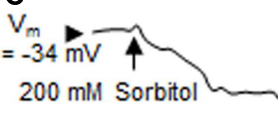

$5 \mathrm{mV}$

D

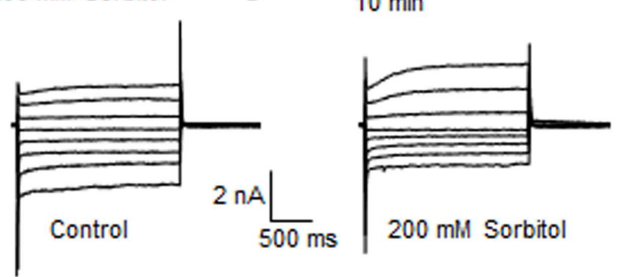

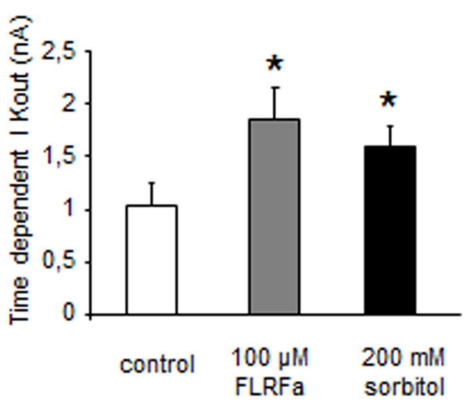

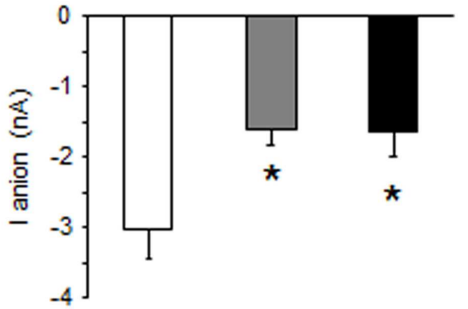

FIGURE 1 | FLRFa-induced hyperpolarization of a cultured cell of Arabidopsis thaliana maintained by a microfunnel and impaled by a microelectrode (A). Modulation of $A$. thaliana whole cell currents in response to $100 \mu \mathrm{M}$ FLRFa (B). Sorbitol induced hyperpolarization (C). Modulation of $A$. thaliana whole cell currents in response to $200 \mathrm{mM}$ sorbitol (D). The protocol was as illustrated, holding potential $\left(V_{h}\right)$ was $V_{m}$. Mean values of anion currents recorded at $-200 \mathrm{mV}$ after $1.8 \mathrm{~s}$ and of time dependent $\mathrm{K}^{+}$outward currents at $+80 \mathrm{mV}$ after $1.8 \mathrm{~s}$ (E). The data correspond to means of four independent experiments and error bars correspond to SD. * Significantly different from controls, $P<0.05$. strongly suggests that functional bioactive FLPs could be synthesized in Arabidopsis, as in metazoans. Surprisingly, practically none of the putative peptides observed in Arabidopsis ended with a G, but with a W instead. This suggests that in Arabidopsis, amidation does not occur when the peptide is generated. This raises the question of the activity of these molecules in Arabidopsis, as amidation appears to be necessary to their bioactivity in metazoans.

The putative presence of RF-amide peptides in plants is, at the moment, based on genomic and transcriptomic databases. Future work should aim at characterizing the presence of translated peptides. However, because of the similarity with the metazoan peptides observed in the peptide ILRF found and whatever the differences around the cleavage site, we have explored their activity in Arabidopsis cells.

\section{PUTATIVE FLPs FROM A. THALIANA COULD REGULATE SORBITOL-INDUCED PCD AND ROS GENERATION}

As in animal cells, plant cell hyperosmotic stress may result in the induction of signaling events that leads to programed cell death (PCD) $(2,43-47)$, an active cellular process that facilitates the removal of unwanted or damaged cells and is essential for cellular differentiation and tissue homeostasis. We recently showed that hyperosmotic stresses-induced ion channel regulations participate in pathways leading to PCD in plant cultured cells (2). Using synthetic peptides, we tested the effect of putative plant FLPs (ILRF and ILKF, $10 \mu \mathrm{M}$ each) on sorbitol-induced PCD in A. thaliana suspension cells. The shifts in osmolality induced by addition of $400 \mathrm{mM}$ sorbitol (from 128 to $524 \mathrm{mOsm}$ ) led to the death of about half of the cell population after $6 \mathrm{~h}$ (Figures 3A,B) when FLPs did not induce a significant increase in cell death (Figure 3A). Pretreatments of $A$. thaliana cells with $10 \mu \mathrm{M}$ ILRF or ILKF 15 min before addition of $400 \mathrm{mM}$ sorbitol decreased the extent of the sorbitolinduced cell death (Figure 3A). Due to the lack of terminal G, which was systematically replaced by a $\mathrm{W}$ in plant sequence, the putative plant FLP could not be amidated (cf data from Figure 2). Thus, we further investigated the putative role of the terminal $W$ by testing the same peptides augmented with a terminal W (ILKFW and ILRFW, $10 \mu \mathrm{M}$ each). These treatments decreased the extent of the sorbitol-induced cell death in the same range (Figure 3A), suggesting no specific role for the terminal $\mathrm{W}$ in this response. It is noteworthy that the terminal amidation did not increase the bioactivity, since the decrease in sorbitol-induced cell death by pretreatment with amidated peptides, ILRFa, ILKFa, and FLRFa $(100 \mu \mathrm{M}$ each), were not drastically modified even with a 10 times higher concentration (Figure 3C).

A delayed $\mathrm{O}_{2}^{-}$generation from NADPH-oxidase activity was also shown to play a central role in the hyperosmotic stressinduced PCD in plant cells (2). We thus evaluated the impact of putative plant FLPs (ILRF, ILKF, ILKFW, and ILRFW, $100 \mu \mathrm{M}$ each) on sorbitol-induced ROS generation. As observed for sorbitol-induced cell death, pretreatments of $A$. thaliana cells with these FLPs $15 \mathrm{~min}$ before addition of $400 \mathrm{mM}$ sorbitol did 


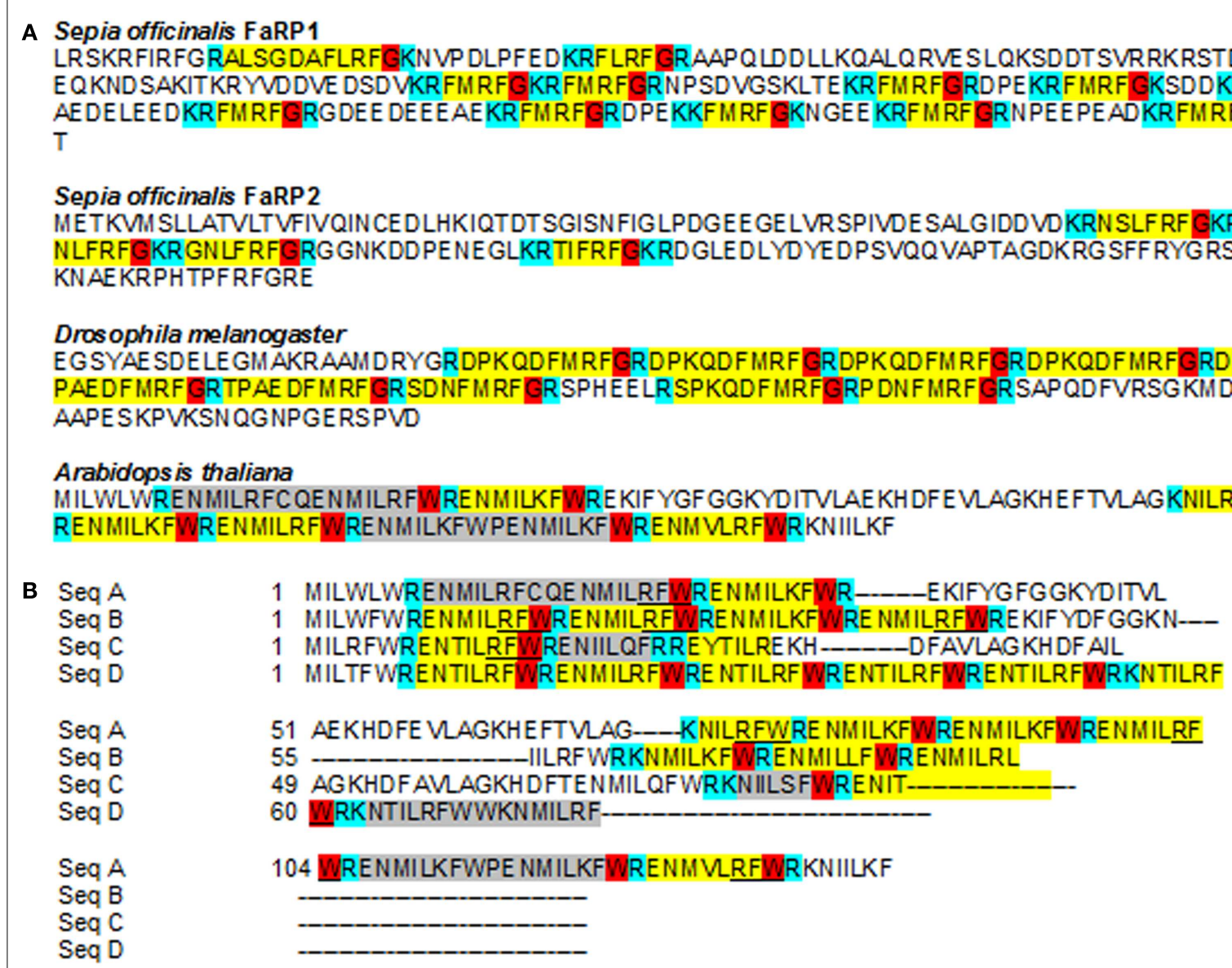

\section{Seq 1}

MILWLWRENMILRFCQE NMILRFWRENMILKFWRE KIFYGFGGKYDITVLAEKHDFE VAGKHEFTMAGKNILRFWRENMILKFW RENMILKFWRENMILRFWRENMILKFWPENMILKFWRENMULRFRKNIILKF

\section{Seq 2}

MDRSTCLQVQDWF GGKIMGLRF WRE NH GFTFLTGKLQWWFGGKITGLRFWRENYRAYF GGKITGLRF WRENYRFTFWRE NHGFTFLAGKLQW MAGKSRWWLRKNYGFTFLQKNHGFTFLAGKLPGLRFWRENHGFTFLAGKLQW MAGKSRVMFLRK NYGFTFLQKNHGFTFLAGKLQWMAGKSWMFGGKITGLRFWRENYRFTFLARKSRWMFAGKLRWMSARKSRWMFWW ENYGFTFWRKNHGFMFFAGKLRWF GGKITGLRFWREYH GFTFLAEKSWM MGGKITGLCFLVEKLRWFFSISSLWLRNLF KNDFIKLV

\section{Seq 3}

MGLRFLWE NLGFTFLVGKSRW WFGGKITGLRFWWENHGFTFLVEKLRWMFWRENYEFTFLASKLRWMFGGKTTGLCFWRK NLGFTFLAGKSRW MFGGKITGLRFWKKIM GLRFWRKNYGFPFLAGNYGFTFLAGKSLWMFGGKIRGLRFWRKNHGFTFLARK SRIYF GGKITGLCFLVENLRWFFSISSHWLRNLEKY

\section{Seq 4}

MYFIYCGGKITDLRFWRKNH GLTFLAENYRFTFLTGKLRWMFGGKITGLRFWRKIIGLRFWREKYGFTFLAGKSRVMFGGKITG LRFLRENHGFTFLAGKYGFTFLAGKSQWWFGGKIIMDLCFWRKISGLRFWRVNHGFTFLAGKSWVFVFGGITGLCFLVEKLRIY FSSISSLYLRNLEKY

\section{Seq 5}

MSKWDIYGFHFLRIYFDEKITGLRFWRKIIGLRFWRENYGFKFLAGKLRWFGGKISGLRFWRENHGFTFLAGKSRVFVF GRKIT GFRFLAEKLRWF GEKITGLRFWRENHGFM FLAGKSWMFGGKITGFTFLAGKSRIYGFTFLAGKLWIYWFGKISDFRFWRE NLGFTFLTRKSR MVGGKITDLCFLVE NLRWFFSISSLYYRNLEKY

showing the diversity of FaRP between species, in the same species and in the same gene. For example, two different genes coding for FaRPs were

(Continued) 


\section{FIGURE 2 | Continued}

characterized in Sepia officinalis with different composition and length. All peptides characterized in metazoans end with a $\mathrm{G}$ allowing amidation of the peptide after cleavage (38). The sequence of $A$. thaliana shows similar repetitions ending with RF but with a W instead of a G. Acc number: $S$. officinalis FaRP1: P91889; S. officinalis FaRP2: D8WXV2; D. melanogaster: AY070639; A. thaliana: P93742. (B) Different putative pro-peptides in A. thaliana genome detected using a poly-ILRF query. Sequences were manually aligned in Jalview. Acc. Numbers: SeqA At2g42050 (P93742_ARATH).1-139; SeqB: BAB01828 (Q9LS63_ARATH)/1-86; SeqC: F26F24.19 (Q9LR27_ARATH_F26F24.19)/1-86; SeqD: F4N2.6_(O9LQB1_ARATH)/1-77. (C) Examples of putative small peptides from $A$. thaliana including a RFW end-sequence (underlined) or terminated by another sequence (highlighted in gray). These sequences are chosen to illustrate the presence of putative pro-peptide genes on each chromosome. Each sequence has been detected in mRNA sequencing (as shown by a tblastn against $A$. thaliana ESTs at the $\mathrm{NCBI}$ site) but are not recognized as ESTs in $A$. thaliana EnsembIPlants genomic automatic annotation due to their repeat structure. Instead, all are flagged as transposable elements. Acc. numbers: A. thaliana: seq1:

P93742_ARATH; seq2: Q9LNR8_ARATH; seq.3: Q9SVC3_ARATH; seq.4: Q9SZF1_ARATH; seq.5: Q9FGB7_ARATH. The putative cleavage sites (mono or dibasic) are indicated in blue, the "transitional peptide" in red, the putative functional peptide in yellow. The sequence highlighted in gray in Arabidopsis sequences is a putative peptide.
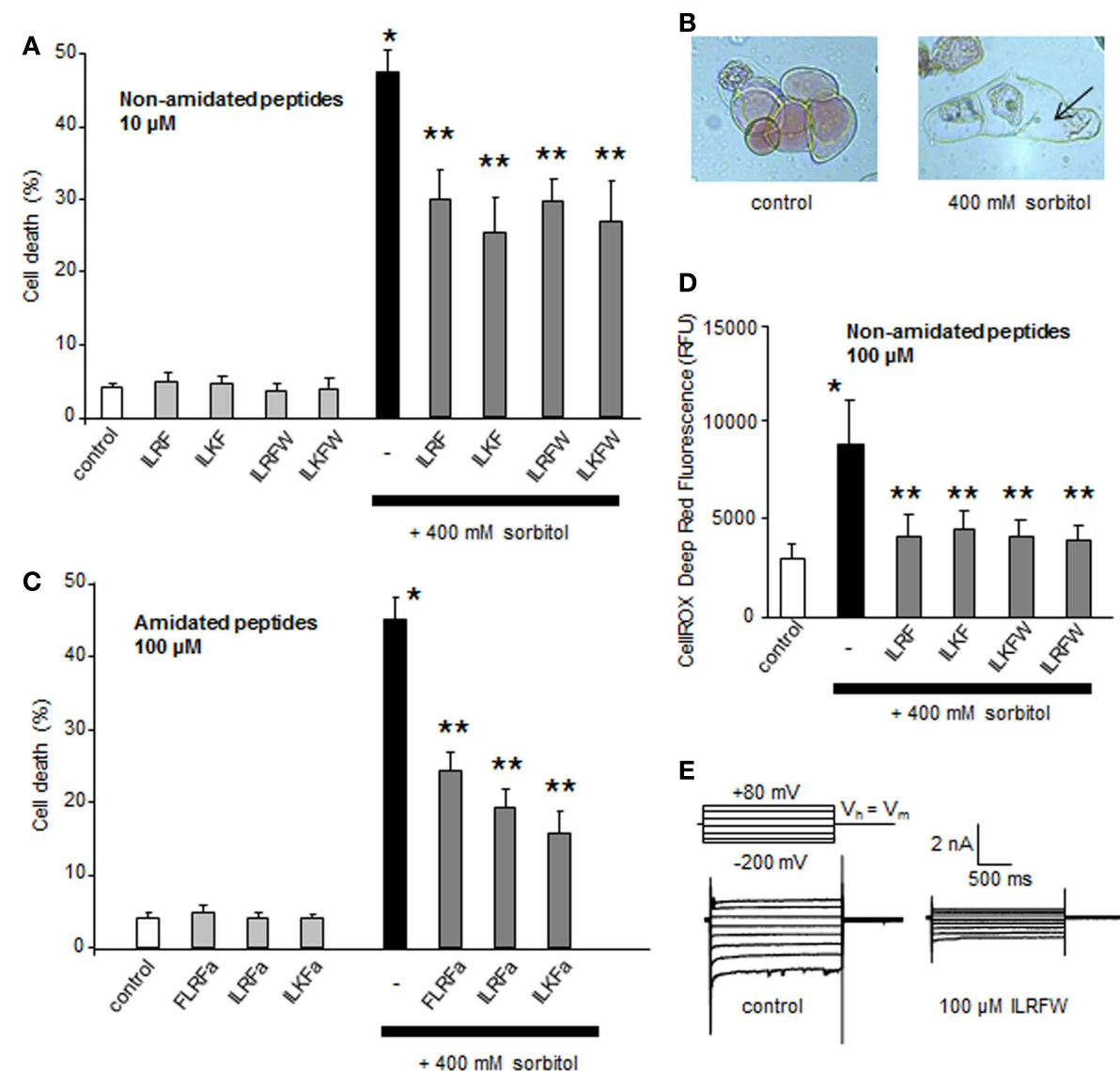

E

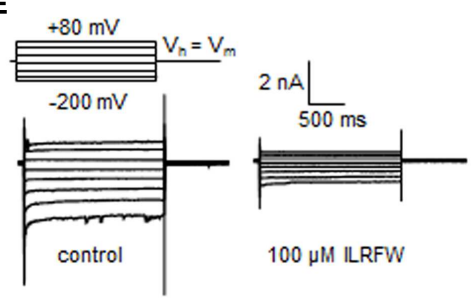

FIGURE 3 | Effect of different putative plant FLPs on sorbitol-induced cell death in Arabidopsis thaliana cells. (A) Effect of non-amidated synthetic FLPS (ILRF, ILKF, ILRFW, and ILKFW, $10 \mu \mathrm{M}$ each) on sorbitol-induced cell death extent. (B) Light micrographs of $A$. thaliana cultured cells stained with Neutral Red $6 \mathrm{~h}$ after incubation with $400 \mathrm{mM}$ sorbitol (right) compared to living control cells maintained in their medium (left). Arrows indicate the cell shrinkage. (C) Effect of various amidated synthetic FLPS (ILRFa, ILKFa, and
FLRFa, $100 \mu \mathrm{M}$ each) on sorbitol-induced cell death extent. (D) Effect of various non-amidated synthetic FLPs (ILRF, ILKF, ILRFW, and ILKFW, $100 \mu \mathrm{M}$ each) on sorbitol-induced ROS generation. Each data point and error bar reflect the mean and SD, respectively, of at least three independent replicates. ${ }^{*}$ Significantly different from controls, $P<0.05$ and ${ }^{* *}$ significantly different from the sorbitol treated cells, $P<0.05$. (E) Inhibition of $A$. thaliana anion current in response to $100 \mu \mathrm{M}$ ILRFW. not cause sorbitol-induced ROS generation (Figure 3D). Moreover, the peptide ILRFW could reduce anion channel activity (Figure 3E) and induce a hyperpolarization of the cells of about $-10 \mathrm{mV}$ (not shown) as does FLRFa (Figure 1A). It is noteworthy that non-amidated putative plant FLPs were efficient in decreasing sorbitol-induced ROS generation and anion currents, indicating that the peptide amidation was not necessary for their activities.

From these data it seems that, like in animal cells, FLPs could participate in osmoregulation through regulation of different events as ROS and PCD. The fact that the early FLP-induced ion current regulations in plant cells are the same as the one 
observed in response to a hyperosmotic stress (Figures 1 and $3 \mathrm{E}$ ) suggests that FLPs could participate to early induced process to maintain ion homeostasis and/or signalization, allowing to limit hyperosmotic stress-induced-PCD progress (Figure 3A).

\section{PUTATIVE FLPS FROM A. THALIANA COULD REGULATE STOMATAL OPENING}

Since putative plant FLPs could inhibit ROS generation (Figure 3D) and anion channel activity (Figures 1B and 3E) both of which are known to regulate the stomatal aperture (48, 49) - we checked for the effect of a putative plant FLP (ILRF) on stomatal regulation. Stomata are pores in the plant epidermis that allow gas exchange between the intercellular spaces to the external environment. Two guard cells surround the stomatal pore, and changes in their turgor pressure regulate the size of the pore aperture allowing the $\mathrm{CO}_{2}$ assimilation and limit excessive water loss by optimizing the aperture in response to the external environment. Epidermal strips from $A$. thaliana leaves were thus floated $2 \mathrm{~h}$ in two different conditions to either optimize the opening (opening buffer) or the closure of the stomata (closing buffer) (29) before addition of $100 \mu \mathrm{M}$ ILRF. No effect could be observed on open stomata in response to addition of ILRF (Figure 4), while the same treatment induced an increase in the aperture of stomata from the epidermal strips placed in the closing buffer (Figure 4).

This ILRF-induced stomatal opening could appear counterintuitive, since upon drought stress, the stomatal closing is thought to be an important primary defense against tissue dehydration (48, 50). However, if such response is part of a fundamental response to severe drought stress, upon mild drought stress, prolonged closed stomata will stop growth by depriving the plant of $\mathrm{CO}_{2}$

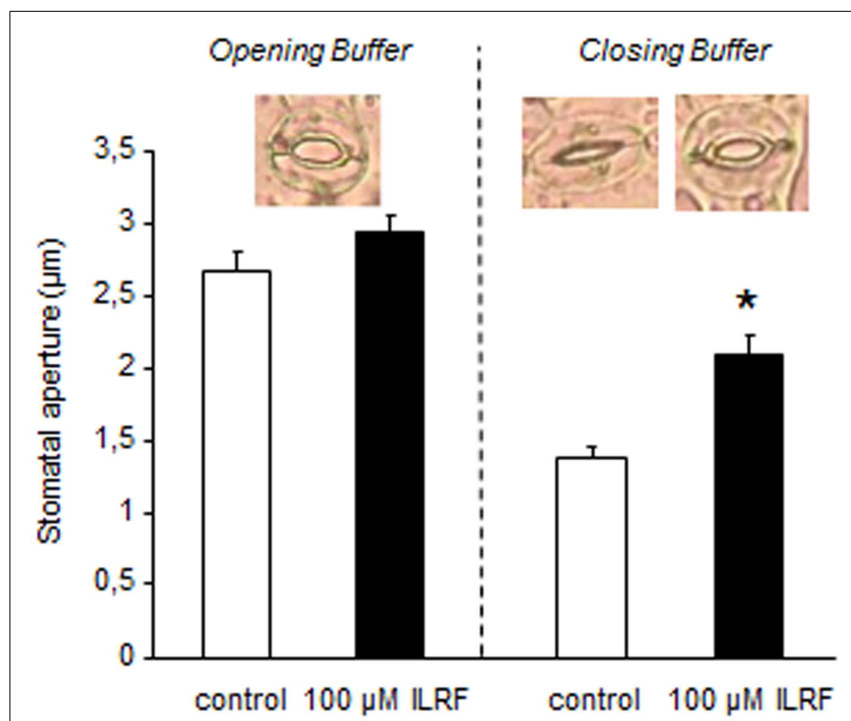

FIGURE 4 | Changes in Arabidopsis stomatal apertures of epidermal strips maintained in opening buffer or closing buffer upon treatment with $100 \mu$ M ILRF. Means \pm SE ( $n=65-75$ stomata for each treatment). * Significant difference $(P<0.05)$ in stomatal aperture when compared to the control was found after treatment with ILRF in closing buffer, but not opening buffer. for photosynthesis. Adaptive plant growth in sporadic water availability will thus depend on the optimal tradeoff between stomatal closing and rapid re-opening capability. Thus, plants should adapt to mild soil water deficit by mechanisms that are distinct from those of severe dehydration. This was highlighted by a recent report in which acetylated 1,3-diaminopropane counteracted the canonical abscisic acid-induced stomatal closing (48) upon mild drought stress, but not upon severe drought stress (51).

\section{CONCLUSION}

Numerous cellular features are conserved in eukaryotic cells (18, 19), and many discoveries with direct relevance to animal biology and even human health and disease have been elaborated using plants (17). In this context, conservation of mechanisms of response to hyperosmotic stress, a stress that most of the living organisms have to face, appears logical. In a recent paper, Aalen (10) mentioned that plant peptide research is coming of age and that plant peptide signaling is of crucial importance for all aspects of plant growth and development. Recent works effectively implicate several families of small signaling peptides in various developmental processes in plants (11). However, the families of characterized peptides in plants represent $<10 \%$ of the estimated number of secreted peptide ligands. Our preliminary results showing that some putative FLPs genes are present in A. thaliana genome and that putative plant FLPs could induce physiological responses involved in hyperosmotic stress responses warrant further studies on this topic. Furthermore, we cannot dismiss the possibility that other genes could be responsible for synthesis of others putative FLPs in plants. Drought frequency may increase by more than $20 \%$ in some regions of the globe by the end of the twenty-first century, with reductions in crop yields due to decreased water availability. Thus, understanding the putative role of FLPs in plants as regulators that mediate environmental influences on plant development and fitness is particularly relevant for plant biology. Moreover, this topic could also be relevant for metazoan biology since it could bring new insight in FLPs structures, functions, and evolution.

\section{ACKNOWLEDGMENTS}

This work was supported by funds "Action Spécifique" from UFR SdV of Université Paris Diderot, Paris 7, and a special donation of Andre Ponticelli. We thank Pascal-Jean Lopez and Joel Henry for helpful discussions. We are grateful to Lori Buhlman for her corrections on the manuscript.

\section{REFERENCES}

1. Hoffmann EK, Lambert IH, Pedersen SF. Physiology of cell volume regulation in vertebrates. Physiol Rev (2009) 89:193-277. doi:10.1152/physrev.00037.2007

2. Monetti E, Kadono T, Tran D, Azzarello E, Arbelet-Bonnin D, Biligui B, et al. Deciphering early events involved in hyperosmotic stress-induced programmed cell death in tobacco BY-2 cells. J Exp Bot (2014) 65:1361-75. doi:10.1093/jxb/ert460

3. Loretz CA, Bern HA. Prolactin and osmoregulation in vertebrates. An update. Neuroendocrinology (1982) 35:292-304. doi:10.1159/000123397

4. McCormick SD. Endocrine control of osmoregulation in teleost fish. Am Zool (2001) 41:781-94. doi:10.1668/0003-1569(2001)041 [0781:ECOOIT]2.0.CO;2

5. Lu W, Abdel-Razik AE, Ashton N, Balment RJ. Urotensin II: lessons from comparative studies for general endocrinology. Gen Comp Endocrinol (2008) 157:14-20. doi:10.1016/j.ygcen.2008.03.010 
6. Webster SG, Keller R, Dircksen H. The CHH-superfamily of multifunctional peptide hormones controlling crustacean metabolism, osmoregulation, moulting, and reproduction. Gen Comp Endocrinol (2012) 175:217-33. doi:10.1016/j. ygcen.2011.11.035

7. Rivas-San Vicente M, Plasencia J. Salicylic acid beyond defence: its role in plant growth and development. J Exp Bot (2011) 62:3321-38. doi:10.1093/jxb/err031

8. Nakashima K, Yamaguchi-Shinozaki K. ABA signaling in stress-response and seed development. Plant Cell Rep (2013) 32:959-70. doi:10.1007/s00299-0131418-1

9. Colebrook EH, Thomas SG, Phillips AL, Hedden P. The role of gibberellin signalling in plant responses to abiotic stress. J Exp Biol (2014) 217:67-75. doi:10.1242/jeb.089938

10. Aalen RB. Maturing peptides open for communication. J Exp Bot (2013) 64:5231-5. doi:10.1093/jxb/ert378

11. Delay C, Imin N, Djordjevic MA. Regulation of Arabidopsis root development by small signaling peptides. Front Plant Sci (2013) 4:352. doi:10.3389/fpls.2013. 00352

12. Kahn HR, Price DA, Doble KE, Greenberg MJ, Saleuddin ASM. Osmoregulation and FMRFamide-related peptides in the salt marsh snail Melampus bidentatus (Say) (Mollusca: Pulmonata). Biol Bull (1999) 196:153-62. doi:10.2307/1542561

13. López-Vera E, Aguilar MB, Heimer de la Cotera EP. FMRFamide and related peptides in the phylum mollusca. Peptides (2008) 29:310-7. doi:10.1016/j.peptides. 2007.09.025

14. Răszer T, Bánfalvi G. FMRFamide-related peptides: anti-opiate transmitters acting in apoptosis. Peptides (2012) 34:177-85. doi:10.1016/j.peptides.2011.04.011

15. Buttner N, Siegelbaum SA. Antagonistic modulation of a hyperpolarizationactivated $\mathrm{Cl}$ current in Aplysia sensory neurons by SCP(B) and FMRFamide. $J$ Neurophysiol (2003) 90:586-98. doi:10.1152/jn.00007.2003

16. Vandorpe DH, Small DL, Dabrowski AR, Morris CE. FMRFamide and membrane stretch as sctivators of the Aplysia S-channel. Biophys J (1994) 66:46-58. doi:10.1016/S0006-3495(94)80749-0

17. Jones AM, Chory J, Dangl JL, Estelle M, Jacobsen SE, Meyerowitz EM, et al. The impact of Arabidopsis on human health: diversifying our portfolio. Cell (2008) 133:939-43. doi:10.1016/j.cell.2008.05.040

18. Mancuso S, Baluska F. Deep evolutionary origins of neurobiology. Commun Integr Biol (2009) 2:60-5. doi:10.4161/cib.2.1.7620

19. Grémiaux A, Yokawa K, Mancuso S, Baluška F. Plant anesthesia supports similarities between animals and plants: Claude Bernard's forgotten studies. Plant Signal Behav (2014) 9:e27886. doi:10.4161/psb.27886

20. Hedrich R. Ion channels in plants. Physiol Rev (2012) 92:1777-811. doi:10.1152/ physrev.00038.2011

21. Li ZS, Delrot S. Osmotic dependence of the transmembrane potential difference of broadbean mesocarp cells. Plant Physiol (1987) 84:895-9. doi:10.1104/pp.84. 3.895

22. Zingarelli L, Marrè MT, Massardi F, Lado P. Effects of hyper-osmotic stress on $\mathrm{K}^{+}$fluxes, $\mathrm{H}^{+}$extrusion, transmembrane electric potential difference and comparison with the effects of fusicoccin. Physiol Plant (1999) 106:287-95. doi:10.1034/j.1399-3054.1999.106305.x

23. Shabala S, Lew RR. Turgor regulation in osmotically stressed Arabidopsis epidermal root cells. Direct support for the role of inorganic ion uptake as revealed by concurrent flux and cell turgor measurements. Plant Physiol (2002) 129:290-9. doi:10.1104/pp.020005

24. Tran D, El-Maarouf-Bouteau H, Rossi M, Biligui B, Briand J, Kawano T, et al. Post-transcriptional regulation of GORK channels by superoxide anion contributes to increases in outward-rectifying $\mathrm{K}^{+}$currents. New Phytol (2013) 198:1039-48. doi:10.1111/nph.12226

25. Kadono T, Tran D, Errakhi R, Hiramatsu T, Meimoun P, Briand J, et al. Increased anion channel activity is an unavoidable event in ozone-induced programmed cell death. PLoS One (2010) 5:e13373. doi:10.1371/journal.pone.0013373

26. Reboutier D, Bianchi M, Brault M, Roux C, Dauphin A, Rona JP, et al. The indolic compound hypaphorine produced by ectomycorrhizal fungus interferes with auxin action and evokes early responses in non-host Arabidopsis thaliana. Mol Plant Microbe Interact (2002) 15:932-8. doi:10.1094/MPMI.2002. 15.9.932

27. Itoh T, Tsuzuki R, Tanaka T, Ninomiya M, Yamaguchi Y, Takenaka H, et al. Reduced scytonemin isolated from Nostoc commune induces autophagic cell death in human T-lymphoid cell line Jurkat cells. Food Chem Toxicol (2013) 60:76-82. doi:10.1016/j.fct.2013.07.016
28. Price DA, Greenberg MJ. Structure of a molluscan cardioexcitatory neuropeptide. Science (1977) 197:670-1. doi:10.1126/science.877582

29. Meimoun P, Vidal G, Bohrer AS, Lehner A, Tran D, Briand J, et al. Intracellular $\mathrm{Ca}^{2+}$ stores could participate to abscisic acid-induced depolarization and stomatal closure in Arabidopsis thaliana. Plant Signal Behav (2009) 4:830-5. doi:10.4161/psb.4.9.9396

30. Brault M, Amiar Z, Pennarun AM, Monestiez M, Zhang Z, Cornel D, et al. Plasma membrane depolarization induced by abscisic acid in Arabidopsis suspension cells involves reduction of proton pumping in addition to anion channel activation, which are both $\mathrm{Ca}^{2+}$ dependent. Plant Physiol (2004) 135:231-43. doi:10.1104/pp.104.039255

31. Pennarun AM, Maillot C. $\mathrm{Cl}^{-}$efflux responding to a turgor drop in cells of Acer pseudoplatanus. Plant Physiol Biochem (1988) 26:117-24.

32. Teodoro AE, Zingarelli L, Lado P. Early changes of $\mathrm{Cl}^{-}$efflux and $\mathrm{H}^{+}$extrusion induced by osmotic stress in Arabidopsis thaliana cells. Physiol Plant (1998) 102:29-37. doi:10.1034/j.1399-3054.1998.1020105.x

33. Shabala S, Babourina O, Newman I. Ion-specific mechanisms of osmoregulation in bean mesophyll cells. J Exp Bot (2000) 51:1243-53. doi:10.1093/jexbot/ 51.348.1243

34. Lew RR. Immediate and steady state extracellular ionic fluxes of growing Arabidopsis thaliana root hairs under hyperosmotic and hypoosmotic conditions. Physiol Plant (1998) 104:397-404. doi:10.1034/j.1399-3054.1998.1040315.x

35. Liu K, Luan S. Voltage-dependent $\mathrm{K}^{+}$channels as targets of osmosensing in guard cells. Plant Cell (1998) 10:1957-70. doi:10.1105/tpc.10.11.1957

36. Greenberg MJ, Price DA. Relationships among the FMRFamide-like peptides. Prog Brain Res (1992) 92:25-37. doi:10.1016/S0079-6123(08)61162-0

37. Liu F, Baggerman G, Schoofs L, Wets G. Uncovering conserved patterns in bioactive peptides in metazoa. Peptides (2006) 27:3137-53. doi:10.1016/j.peptides. 2006.08.021

38. Espinoza E, Carrigan M, Thomas SG, Shaw G, Edison AS. A statistical view of FMRFamide neuropeptide diversity. Mol Neurobiol (2000) 21:35-56. doi:10. 1385/MN:21:1-2:035

39. Hook V, Funkelstein L, Lu D, Bark S, Wegrzyn J, Hwang S-R. Proteases for processing proneuropeptides into peptide neurotransmitters and hormones. Annu Rev Pharmacol Toxicol (2008) 48:393-423. doi:10.1146/annurev.pharmtox.48. 113006.094812

40. Loi P, Saunders R, Young D, Tublitz N. Peptidergic regulation of chromatophore function in the European cuttlefish Sepia officinalis. J Exp Biol (1996) 199:1177-87.

41. Messenger JB. Cephalopod chromatophores: neurobiology and natural history. Biol Rev Camb Philos Soc (2001) 76:473-528. doi:10.1017/S1464793101005772

42. Zhang Z, Goodwin E, Loi PK, Tublitz NJ. Molecular analysis of a novel FMRFamide-related peptide gene $(\operatorname{SOFaRP}(2))$ and its expression pattern in the brain of the European cuttlefish Sepia officinalis. Peptides (2012) 34:114-9. doi:10.1016/j.peptides.2011.07.011

43. Huh GH, Damsz B, Matsumoto TK, Reddy MP, Rus AM, Ibeas JI, et al. Salt causes ion disequilibrium-induced programmed cell death in yeast and plants. Plant J (2002) 29:649-59. doi:10.1046/j.0960-7412.2001.01247.x

44. Affenzeller MJ, Darehshouri A, Andosch A, Lütz C, Lütz-Meindl U. Salt stressinduced cell death in the unicellular green alga Micrasterias denticulata Matthias. J Exp Bot (2009) 60:939-54. doi:10.1093/jxb/ern348

45. Wang J, Li X, Liu Y, Zhao X. Salt stress induces programmed cell death in Thellungiella halophila suspension-cultured cells. J Plant Physiol (2010) 167:1145-51. doi:10.1016/j.jplph.2010.03.008

46. Chiong M, Parra V, Eisner V, Ibarra C, Maldonado C, Criollo A, et al. Parallel activation of $\mathrm{Ca}^{2+}$-induced survival and death pathways in cardiomyocytes by sorbitol-induced hyperosmotic stress. Apoptosis (2010) 15:887-903. doi:10.1007/s10495-010-0505-9

47. Withanage K, Nakagawa K, Ikeda M, Kurihara H, Kudo T, Yang Z, et al. Expression of RASSF6 in kidney and the implication of RASSF6 and the hippo pathway in the sorbitol-induced apoptosis in renal proximal tubular epithelial cells. J Biochem (2012) 152:111-9. doi:10.1093/jb/mvs056

48. Sirichandra C, Wasilewska A, Vlad F, Valon C, Leung J. The guard cell as a singlecell model towards understanding drought tolerance and abscisic acid action. $J$ Exp Bot (2009) 60:1439-63. doi:10.1093/jxb/ern340

49. Negi J, Hashimoto-Sugimoto M, Kusumi K, Iba K. New approaches to the biology of stomatal guard cells. Plant Cell Physiol (2014) 55:241-50. doi:10.1093/ pcp/pct145 
50. Schroeder JI, Allen GJ, Hugouvieux V, Kwak JM, Waner D. Guard cell signal transduction. Annu Rev Plant Physiol Plant Mol Biol (2001) 52:627-58. doi:10.1146/annurev.arplant.52.1.627

51. Jammes F, Leonhardt N, Tran D, Bousserouel H, Very AA, Renou JP, et al. Acetylation of 1,3-diaminopropane by NATAl can antagonize abscisic acid-mediated stomatal closing in Arabidopsis. Plant J (2014) 79:322-33. doi:10.1111/tpj.12564

Conflict of Interest Statement: The authors declare that the research was conducted in the absence of any commercial or financial relationships that could be construed as a potential conflict of interest.

Received: 24 May 2014; accepted: 28 July 2014; published online: 14 August 2014.
Citation: Bouteau F, Bassaglia Y, Monetti E, Tran D, Navet S, Mancuso S, El-MaaroufBouteau H and Bonnaud-Ponticelli L (2014) Could FaRP-like peptides participate in regulation of hyperosmotic stress responses in plants? Front. Endocrinol. 5:132. doi: 10.3389/fendo.2014.00132

This article was submitted to Neuroendocrine Science, a section of the journal Frontiers in Endocrinology.

Copyright (c) 2014 Bouteau, Bassaglia, Monetti, Tran, Navet, Mancuso, El-MaaroufBouteau and Bonnaud-Ponticelli. This is an open-access article distributed under the terms of the Creative Commons Attribution License (CC BY). The use, distribution or reproduction in other forums is permitted, provided the original author(s) or licensor are credited and that the original publication in this journal is cited, in accordance with accepted academic practice. No use, distribution or reproduction is permitted which does not comply with these terms. 